Poznańskie Studia Teologiczne 29(2015), s. 183-196.

doi: $10.14746 /$ pst.2015.29.10

Bogdan Ferdek ${ }^{1}$

Papieski Wydział Teologiczny we Wrocławiu

\title{
Spór o nieomylność papieża - od Haec sancta do Pastor aeternus
}

Dziełem Soboru Watykańskiego I są dwie konstytucje: Konstytucja dogmatyczna o wierze katolickiej Dei Filius ${ }^{2}$ i Pierwsza konstytucja dogmatyczna o Kościele Chrystusowym Pastor aeternus ${ }^{3}$. Druga spośród wymienionych tutaj konstytucja Pastor aeternus zawiera dwa dogmaty: o prymacie biskupa Rzymu i o jego nieomylnym nauczaniu. W kręgach ich przeciwników mówiono, że sobór ten rozpoczął się od „komedii zaproszeń”, a zakończył się „,tragedią nieomylności”4. Sformułowanie „komedia zaproszeń” nawiązuje do inicjatyw Piusa IX, który pismem Arcano divinae providentiae zaprosił wszystkich biskupów obrządku wschodniego niezachowujących wspólnoty z Rzymem, aby przybyli na sobór, ponieważ ich poprzednicy byli na Soborze Lyońskim II oraz Florenckim. Natomiast w piśmie Iam vos omnes noveritis Pius IX wezwał wszystkich protestantów, aby przyłączyli się do jedynej owczarni Chrystusa. Z kolei „tragedią nieomylności” była posoborowa schizma i spory wewnątrz Kościoła. Od 1871 roku rozpoczął się proces tworzenia Kościoła starokatolickiego, który został uwieńczony 14 czerwca 1873 roku wyborem Josepha Huberta Reinkensa na pierwszego starokatolickiego biskupa. Reinkers był profesorem na Wydziale Teologicznym Śląskiego Uniwersytetu Friedricha Wilhelma w Breslau (Wrocław). W latach 1865/1866 pełnił funkcję rektora tegoż uniwersytetu. Jest autorem książki Über päpstliche Unfehlbarkeit: einige Reflexionen wydanej w München w 1870 roku. Według Reinkensa Sobór Watykański I zniósł episkopat na rzecz papieża, który został uczyniony wice-Bogiem ${ }^{5}$. Jest to sprzeczne z Biblią, która nie zna słów

\footnotetext{
${ }^{1}$ Urodzony w 1956 r. w Ozimku; wykładowca teologii dogmatycznej na Papieskim Wydziale Teologicznym we Wrocławiu; członek Komitetu Nauk Teologicznych PAN; konsultor Komisji Nauki Wiary przy KEP.

${ }^{2}$ Zob. Sobór Watykański I, Konstytucja dogmatyczna o wierze katolickiej, w: Dokumenty Soborów Powszechnych IV, Kraków 2004, s. 888-911.

${ }^{3}$ Zob. Sobór Watykański I, Pierwsza Konstytucja dogmatyczna o Kościele Chrystusowym, w: Dokumenty Soborów Powszechnych IV, dz. cyt., s. 912-927.

${ }^{4}$ K. Schatz, Vaticanum I 1869-1870 III, Paderborn-München-Wien-Zürich 1994.

${ }^{5}$ J. Reinkens, Über päpstliche Unfehlbarkeit: einige Reflexionen, München 1870, s. 144.
} 
Jezusa: „Piotrze, Ja jestem z Tobą”, ale zna inne: „Bo gdzie są dwaj albo trzej zebrani w imię moje, tam jestem pośród nich" (Mt 18,20). Ze względu na te słowa papież Grzegorz Wielki czcił postanowienia soboru jak Ewangelię, a od Piusa IX - wbrew tym słowom - sobory będą czciły papieża jak Ewangelię. Takie wywyższenie papieża kosztem biskupów nazywał Reinkens „samobójstwem Kościoła"6. O posoborowych sporach w diecezji Breslau (Wrocław) może świadczyć wypowiedź ordynariusza tej diecezji Heinricha Förstera o „kotle czarownic” (Hexenkessel), którym stała się jego diecezja ${ }^{7}$. „Tragedia nieomylności” trwa nadal. Dogmat o nieomylności wciąż wywołuje spory. Jako przykład może służyć książka Hansa Künga Nieomylny? Teolog z Tübingen, próbując zreinterpretować dogmat o nieomylnym nauczaniu biskupa Rzymu, doszedł do jego zakwestionowania. Według Künga nieomylny jest tylko Bóg i dlatego Kościół, który Bogiem nie jest, nie może być nieomylny, czyli może się on mylić i innych w błąd wprowadzać 8 .

Ze względu na wciąż trwającą ,tragedię nieomylności” warto pochylić się nad dogmatem o nieomylnym nauczaniu biskupa Rzymu i przypomnieć o okolicznościach jego powstania, o zakresie władzy papieża i ukazać jego otwartość na włączenie w większą całość. Wśród autorów, którzy opracowali to zagadnienie, wyróżnia się Klaus Schatz, profesor historii Kościoła w Philosophisch-Theologische Hochschule Sankt Georgen we Frankfurcie nad Menem, autor trzytomowej pracy Vaticanum I 1869-1870. Trzeci tom tej monografii: Unfehlbarkeitsdiskussion und Rezeption ukazuje okoliczności ogłoszenia dogmatu o nieomylnym nauczaniu biskupa Rzymu. Zagadnienie to dochodzi również do głosu w znanej pracy Hansa Ursa von Balthasara Antyrzymski resentyment.

W literaturze dotyczącej zagadnienia nieomylnego nauczania biskupa Rzymu podkreśla się, że ni e o my lno ść jest przymiotem Boga i dlatego może lepszym terminem w odniesieniu do papieskich wypowiedzi byłaby b e z błę dn o ść. Skoro jednak termin ni e o m ylność wszedł do języka kościelnego i teologicznego, to należałoby podkreślać, że nieomylne nauczanie biskupa Rzymu partycypuje w nieomylności Boga, który zachowuje je od błędu. Ni e o m y lno ść w odniesieniu do biskupa Rzymu byłaby udzielonym mu charyzmatem, dzięki któremu niektóre jego wypowiedzi są wolne od błędu9.

Zagadnienie nieomylnego nauczania biskupa Rzymu zostanie ukazane w czterech odsłonach, którymi są: historyczny kontekst dogmatu, argumenty jego zwolenników i przeciwników, analiza definicji dogmatycznej, relektura dogmatu we współczesnym kontekście.

\footnotetext{
${ }^{6}$ Tamże, s. 158.

${ }^{7}$ Tamże, s. 220.

${ }^{8}$ H. Küng, Nieomylny?, Kraków 1995, s. 175.

${ }^{9}$ Por. W. Beinert, Unfehlbarkeit, w: Lexikon für Theologie und Kirche X, Freiburg-Basel-Wien 2006, s. 389.
} 


\section{Historyczny kontekst dogmatu o nieomylnym nauczaniu biskupa Rzymu}

Dogmaty rodziły się najczęściej w sporach teologicznych. Dogmat o nieomylnym nauczaniu biskupa Rzymu rodził się ze sporu pomiędzy koncyliaryzmem a ultramontanizmem.

Koncyliaryzm doszedł do głosu na Soborze w Konstancji (1414-1418). Sobór ten złożył z urzędu trzech równocześnie urzędujących papieży: Benedykta XIII, Grzegorza XII i Jana XXIII. Następnie wybrał (11 listopada 1417) nowego papieża Marcina V. Zanim jednak to zrobił, wydał (6 kwietnia 1415) dekret Haec sancta, który w punkcie drugim zawiera następujące oświadczenie: sobór jest

prawowicie zgromadzony w Duchu Świętym, stanowi sobór powszechny, reprezentujący Kościół walczący i posiada władzę bezpośrednio od Chrystusa. Każdy, niezależnie od zajmowanej pozycji czy godności, z papieską włącznie, zobowiązany jest do posłuszeństwa względem niego $\mathrm{w}$ sprawach dotyczących wiary i przezwyciężenia obecnej schizmy, jak również ogólnej reformy Kościoła Bożego w głowie i człon$\operatorname{kach}^{10}$.

Haec sancta dekretuje więc wyższość soboru nad papieżem, czyli koncyliaryzm. Podziemnym nurtem koncyliaryzmu, zadekretowanego przez Haec sancta, był np. gallikanizm. Cztery artykuły gallikańskie z 1682 roku nawiązują do Haec sancta. Według drugiego ,artykułu gallikańskiego” papież dysponuje pełnią władzy duchownej, jednak dekrety Soboru w Konstancji dotyczące powagi soborów powszechnych utrzymują nadal swoją moc. Z kolei czwarty ,artykuł gallikański” powiada, że w sprawach wiary papież ma pierwszeństwo, ale jego orzeczenia są niezmienne tylko wtedy, gdy nastąpi zgoda Kościoła ${ }^{11}$. Gallikanizm głosi więc nadrzędność soboru nad papieżem, a nawet uzależnia jego nauczanie w sprawach wiary od ogólnokościelnego konsensusu. Oznacza to ujmowanie w nawias każdej decyzji papieskiej, bo można się od niej odwołać do soboru lub do całego Kościoła. Nie bez racji określa się gallikanizm jako „kościelny parlamentaryzm", według którego władza ustawodawcza w Kościele należy do soborów, a władza wykonawcza do papieża i biskupów ${ }^{12}$. Gallikanizm odmawiał więc papieżowi prawa do podejmowania ostatecznej decyzji w sprawach wiary.

Przeciwieństwem gallikanizmu jest ultramontanizm (łac. 'ponad górami') - pogardliwa nazwa, jaką się posługiwali gallikanie na oznaczenie tych wszystkich, którzy nadmiernie wywyższali władzę papieską i wszystkich rozwiązań oczekiwali „,spoza Alp”, czyli z Rzymu. Według przedstawicieli ultramontanizmu papież jest

\footnotetext{
${ }^{10}$ Sobór w Konstancji, Haec sancta, w: Dokumenty Soborów Powszechnych III, Kraków 2003, s. 49.

${ }^{11}$ Cztery artykuty gallikańskie francuskiego zgromadzenia kleru z 19 marca 1862 roku, w: K. Schatz, Prymat papieski od poczatków do wspótczesności, Kraków 2004, s. 267-268.

${ }^{12}$ K. Schatz, Prymat papieski od poczqutków do wspótczesności, dz. cyt., s. 201.
} 
nieomylny niezależnie od Kościoła, i to do tego stopnia, że od jego nieomylności zależy nieomylność Kościoła. W konsekwencji papież jest niezależny od Kościo$\mathfrak{1 a}^{13}$. Gaspard Mermillod (1824-1892), szwajcarski biskup i kardynał, głosił potrójne wcielenie Syna Bożego: w łonie Dziewicy Maryi, w Eucharystii i w ,starcu na Watykanie". Konsekwencją tego trzeciego wcielenia jest nieomylność papieża. Z kolei Bartolomeo D’Avanzo (1811-1884), włoski biskup i kardynał, twierdził, że nieomylne nauczanie papieża jest wynikiem wcielenia nadprzyrodzonego porządku w biskupa Rzymu. Dzięki temu w jego nauczaniu wszystkie ludy widzą ten nadprzyrodzony porządek ${ }^{14}$. Znany niemiecki teolog Mattias Scheeben (1835-1888), wielki specjalista z zakresu charytologii, porównywał nieomylność papieża z niepokalanym poczęciem Matki Pana. Obydwie prawdy wiary oznaczają radykalne uzdrowienie natury przez łaskę i panowanie łaski nad natura. Łaska zarówno w Maryi, jak i w nieomylnym nauczaniu papieża odnosi zwycięstwo nad Szatanem. Szatan może zmiażdżyć tylko piętę papieża, którą jest jego ziemska władza, ale nie może zniszczyć pozycji papieża w Kościele. W papieżu koncentruje się nadprzyrodzona istota Kościoła do tego stopnia, że nieomylny papież jest tronem Chrystusa ${ }^{15}$. Najbardziej rozpoznawalny ultramontanista, angielski teolog i kardynał Henry Manning (1808-1892), uważał, że Chrystus najpierw wybrał Piotra, a dopiero potem pozostałych apostołów i dlatego prymat Piotra jest kluczem do zrozumienia Kościoła, a nie odwrotnie ${ }^{16}$. William George Ward (1812-1882), angielski filozof i teolog, zreasumował ultramontanizm w życzeniu, aby każdego dnia wraz ze śniadaniem i „Timesem” otrzymywać nieomylną encyklikę papieską ${ }^{17}$. Ultramontanizm w przeciwieństwie do gallikanizmu przyznaje papieżowi taką władzę nad Kościołem, że wręcz utożsamia papieża z Kościołem.

Dogmat o nieomylnym nauczaniu biskupa Rzymu jest więc skutkiem procesów historycznych: z jednej strony gallikanizmu o kilkuwiekowej tradycji, a z drugiej strony stosunkowo młodego ultramontanizmu. Przez ogłoszenie dogmatu o nieomylnym nauczaniu biskupa Rzymu Sobór Watykański I chciał ostatecznie odrzucić gallikanizm.

\section{Argumenty zwolenników i przeciwników nieomylnego nauczania biskupa Rzymu}

W zasadzie na Soborze nie było radykalnych przeciwników nieomylnego nauczania biskupa Rzymu. Dyskusje pomiędzy ojcami Soboru dotyczyły związku nieomylności papieskiej z nieomylnością Kościoła. Wszyscy biskupi byli więc

\footnotetext{
${ }^{13}$ Tamże, s. 211-212.

${ }^{14}$ Tamże, s. 224-225.

${ }^{15}$ K. Schatz, Vaticanum I 1869-1870, dz. cyt., s. 286-287.

${ }^{16}$ Tamże, s. 284.

${ }^{17}$ K. Schatz, Prymat papieski od początków do wspótczesności, dz. cyt., s. 224.
} 
infallibilis t a mi. Jednak mniejsza część biskupów, których można by nazwać minimalistycznymi infallibilistami, podkreślała związek nieomylności papieskiej z nieomylnością Kościoła. Gdy papież mówi w sposób nieomylny, jest wówczas ustami, rzecznikiem i reprezentantem całego Kościoła. Pomoc Ducha Świętego nie jest mu dana bezpośrednio, ale pośrednio poprzez słuchanie Kościoła. Przywoływano św. Antonina z Florencji (1389-1459), który twierdził, że papież nie jest nieomylny, gdy ogłasza definicję z własnej inicjatywy, ale wtedy, gdy posługuje się radą i pomocą całego Kościoła. Papież jest więc nieomylny, gdy opiera się na tradycji Kościoła lub na jego świadectwie ${ }^{18}$. Nieomylność papieska byłaby więc wyrazem nieomylności Kościoła. Natomiast większość biskupów, których można by nazwać maks y mali s ty c zny mi i n f a ll i b i l is t a mi, postrzegała papieża jako źródło nieomylności całego Kościoła. Kościół byłby więc nieomylny dzięki papieżowi. Zwolennikom tak rozumianej nieomylności papieskiej bliski był pogląd francuskiego benedyktyna Prospera Guérangera, że papież niczego nie otrzymuje od Kościoła, tak jak Piotr niczego nie otrzymał od apostołów. Piotr zajmuje miejsce Jezusa Chrystusa, tak jak biskupi zajmują miejsce apostołów ${ }^{19}$.

Pomiędzy zwolennikami obydwu koncepcji papieskiej nieomylności toczyła się burzliwa dyskusja. Na auli soborowej padały wszystkie znane argumenty za nieomylnym nauczaniem biskupa Rzymu i przeciw niemu.

Maksymalistyczni infallibiliści powoływali się na trzy klasyczne teksty petrynistyczne: Mt 16,18, Łk 22,31 i J 21,15-17. Według Mt 16,18 Kościół nie zostanie pokonany przez bramy piekielne, ponieważ jest zbudowany na fundamencie, którym jest Piotr. Z tego fundamentu wyrasta nieomylność Kościoła, Łk 22,32 wskazuje zaś na dwie obietnice dane Piotrowi. Pierwsza z nich dotyczy zachowania wiary Piotra i odnosi się osobiście do niego. Z kolei druga obietnica dotyczy również jego następców, a jej przedmiotem jest publiczne głoszenie prawdziwej wiary. Gdy zaś chodzi o tekst J 21,15-17, to zwracano uwage,

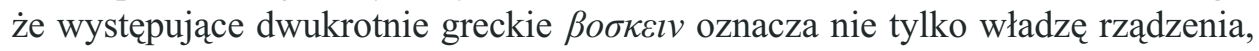
lecz również „dawanie pokarmu”, co wskazuje na nauczanie. Zatem Piotr i jego następcy mają także władzę nauczania. Minimalistyczni infallibiliś c i kontrargumentowali, powołując się na inne wypowiedzi Nowego Testamentu: Ef 2,20 pozostałych apostołów nazywa fundamentem, a Mt 18,18 również im wszystkim przyznaje władzę wiązania i rozwiązywania. Piotr nie jest zatem izolowany od pozostałych apostołów, lecz działa razem z nimi, będąc rzecznikiem wypowiadającym ich wiarę. Z kolei tekst $Ł k$ 22,31 nie znajduje żadnej ilustracji w Nowym Testamencie. Ukazuje on natomiast sobór w Jerozolimie, na którym Piotr rozstrzyga razem $\mathrm{z}$ innymi ${ }^{20}$.

\footnotetext{
18 Tamże, s. 233.

${ }^{19}$ Tamże, s. 234.

${ }^{20}$ Tamże, s. 48-49.
} 
Maksymalistyczni infallibiliści twierdzili, że papież zawsze rozstrzygał definitywnie i nieodwołalnie w sprawach wiary, a sobory były tylko pomocniczym instrumentem jego urzędu nauczycielskiego. Na taki argument minimalistyczni infallibiliści odpowiadali, że w starożytnym Kościele nigdy w czasie licznych sporów nie odwoływano się wprost do papieża. Zamiast tej łatwej i szybkiej drogi rozwiązania sporu wybierano drogę o wiele trudniejszą i wolniejszą, zwołując sobory. Dopiero wypracowywane w trudzie Consensio ecclesiarum uznawał papież ${ }^{21}$.

Maksymalistyczni infallibiliści odwoływali się do aklamacji ojców Soboru Chalcedońskiego: „Piotr przemówił przez Leona”. Na to m in i malistyczni infallibiliści przywoływali przypadek papieża Honoriusza, który jako heretyk został potępiony przez III Sobór w Konstantynopolu ${ }^{22}$.

Hasłem wywoławczym maksymalistycznych infallibilistów były słowa św. Augustyna: Roma locuta, causa finita, któremu min i mali styczni infallibiliści przeciwstawiali słowa Wincentego z Lerynu: Quod semper, quod ubique, quod ab omnibus ${ }^{23}$.

W głosowaniu nad ostateczną wersją definicji dogmatycznej o nieomylnym nauczaniu biskupa Rzymu 13 lipca 1870 roku brało udział 601 ojców Soboru, 451 z nich zagłosowało Placet, 62 - Placet iuxta modum i 88 - Non placet. Po tym głosowaniu 56 ojców opuściło Sobór. W ostatecznym głosowaniu nad ogłoszeniem dogmatu 18 lipca 1870 roku z 535 ojców 533 głosowało Placet, a tylko dwóch Non placet.

\section{Analiza definicji dogmatycznej}

Uroczyście ogłoszona prawda wiary o nieomylnym nauczaniu biskupa Rzymu ma następującą treść:

My zatem, wiernie zachowując tradycję otrzymaną od początku wiary chrześcijańskiej, na chwałę Boga, naszego Zbawiciela, dla wywyższenia religii katolickiej i dla zbawienia narodów chrześcijańskich, za zgodą świętego soboru, nauczamy i definiujemy jako dogmat objawiony przez Boga, że gdy biskup Rzymu przemawia ex cathedra, to znaczy, gdy wykonując urząd pasterza i nauczyciela wszystkich chrześcijan, na mocy swego najwyższego apostolskiego autorytetu określa naukę dotyczącą wiary lub moralności obowiązującą cały Kościół, dzięki opiece Bożej obiecanej mu w [osobie] św. Piotra wyróżnia się tą nieomylnością, w jaką boski Zbawiciel zechciał wyposażyć swój Kościół dla definiowania nauki wiary lub moralności. Dlatego takie definicje biskupa Rzymu - same z siebie, a nie na mocy zgody Kościoła - są niezmienialne ${ }^{24}$.

\footnotetext{
${ }^{21}$ Tamże, s. 52-53.

${ }^{22}$ Tamże, s. 56-57.

${ }^{23}$ Tamże, s. 54-55.

${ }^{24}$ Sobór Watykański I, Pierwsza Konstytucja dogmatyczna o Kościele Chrystusowym, dz. cyt.,
} 
Warunkiem nieomylności papieskiej jest nauczanie ex cathedra. Takie nauczanie ma miejsce wtedy, gdy papież, angażując swój apostolski autorytet, występuje jako pasterz i nauczyciel wszystkich wiernych. Do nauczania ex cathedra należy również intencja ostatecznego rozstrzygnięcia w sprawach wiary i moralności wraz ze zobowiązaniem wiernych do zachowania tego rozstrzygnięcia. Ta intencja powinna być wyraźnie sformułowana. Jeżeli papież wypowiada się jako teolog lub biskup diecezji rzymskiej, to nie jest nieomylny. Nie każda zatem wypowiedź papieża jest nieomylna, lecz tylko ta, która spełnia warunki nauczania ex cathedra ${ }^{25}$. Przymiot nieomylności nie przysługuje więc papieżowi habitualnie, lecz aktualnie, czyli w jednoznacznie opisywalnych sytuacjach ${ }^{26}$. Jako osoba prywatna papież może nawet popaść w herezję, o czym pisał m.in. Robert Bellarmin (1542-1621). Według tego teologa:

Papież, będący jawnym heretykiem automatycznie (per se) przestaje być papieżem i głową Kościoła, jako że natychmiast przestaje być chrześcijaninem (katolikiem) oraz członkiem Kościoła. Z tego powodu może on być sądzony i ukarany przez Kościół. Jest to zgodne z nauką wszystkich Ojców [Kościoła], którzy nauczali, że jawni heretycy natychmiast tracą wszelką jurysdykcję $e^{27}$.

Zakresem nieomylności papieskiej są sprawy wiary lub moralności. W Konstytucji dogmatycznej o wierze katolickiej Dei Filius Sobór Watykański I określił, że wiara jest „cnotą nadprzyrodzoną, przez którą wierzymy, pod wpływem natchnienia i z pomocą łaski Bożej, że prawdą jest to, co Bóg objawił”28. Wiara obejmuje zatem całą prawdę objawioną przez Boga. Z kolei moralność (mores), zdaniem soborowego teologa i późniejszego kardynała, Jana Chrzciciela Franzelina, oznacza zasady moralne, które bezpośrednio wynikają z wiary. Termin mo-

s. 925-926. „Itaque nos traditioni a fidei christianae exordio perceptae fideliter inhaerendo, ad Dei salvatoris nostri gloriam, religionis catholicae exaltationem et christianorum populorum salutem, sacro aprobante concilio, docemus et divinitus revelatum dogma esse difinimus: Romanum pontificem, cum ex cathedra loquitur, id est, cum omnium christianorum pastoris et doctoris munere fungens, pro suprema sua apostolica auctoritate doctrinam de fide vel moribus ab universa ecclesia tenendam definit, per assistentiam divinam, ipsi in beato Petro promissam, ea infallibilitate pollere, qua divinus Redemptor ecclesiam suam in definienda doctrina de fide vel moribus instructam esse voluit; ideoque eiusmodi Romani pontificis definitiones ex sese, non autem ex consensu ecclesiae irreformabiles esse".

${ }^{25}$ L. Ott, Fundamentals of catholic dogma, Charlotte 1974, s. 287.

${ }^{26}$ H. Seweryniak, Rozwój historyczny pojęcia i roli magisterium, w: Charyzmat osoby i autorytet urzędu, red. G. Strzelczyk, Katowice 2007, s. 19.

${ }^{27}$ Robertus Bellarminus, De controversiis christiane fidei adversus hujus temporis haereticos I, lib. II: De Romano Pontifice, cap. 30, w: tenże, Opera omnia I, Napoli 1836, s. 418-420. „Est ergo quinta opinio vera, papam haereticum manifestum per se desinere esse papam et caput, sicut per se desinit esse christianus et membrum corporis Ecclesiae; quare ab Ecclesia posse eum judicari et puniri".

${ }^{28}$ Sobór Watykański I, Konstytucja dogmatyczna o wierze katolickiej, dz. cyt., s. 897. 
res oznacza zatem doctrina revelata practica ${ }^{29}$. Mores są zatem częścią depozytu wiary, zawierającą należącą do objawienia doktrynę moralną, która obejmuje treści o charakterze praktycznym będące konsekwencją i realizacją wiary w życiu ${ }^{30}$.

Źródłem papieskiej nieomylności jest opieka Boża obiecana św. Piotrowi. Piotr nie za pomocą konsultacji z apostołami lub za ich zgoda, ale z pomocą Ojca, który jest $\mathrm{w}$ niebie, sformułował najważniejszy dogmat chrześcijańskiej wiary o Jezusie Synu Boga żywego. Tak jak Ojciec, który jest w niebie, objawił Piotrowi, że Jezus jest Mesjaszem, Synem Boga żywego (Mt 16,17), tak również ten sam Ojciec objawia następcom Piotra to, co należy do wyznania wiary. Pomoc Ojca, który jest w niebie, udzielana następcom Piotra, nie jest przy tym jakimś nowym dodatkiem do objawienia dokonanego w Chrystusie. Nie jest to też natchnienie, dzięki któremu zostało spisane objawienie dokonane w Chrystusie. Ojciec, który jest w niebie, zachowuje następców Piotra od błędu i udziela im łaski, dzięki której mogą właściwie i prawidłowo wyrazić prawdę objawioną. Tę opiekę Bożą można nazwać asystencją ${ }^{31}$. Hans Urs von Balthasar uważa, że n i e o m y ln ość nie jest trwałym przymiotem biskupa Rzymu, lecz ogranicza się ona do aktu, w którym wspomagany przez asystencję Ducha Świętego sprawuje on funkcję nauczyciela wiary i moralności dla całego Kościoła ${ }^{32}$. Dla ludzi nieomylne nauczanie biskupa Rzymu uchodzi za niemożliwe, bo „w ułomnych ziemskich naczyniach słów i pojęć musi ujmować treści niesłychane, przekraczające wszelką myśl i rozumienie, nadając im przy tym charakter oficjalny i zobowiązujący"33. Dla Ducha Świętego nie ma jednak rzeczy niemożliwych. Dzięki Jego asystencji możliwe jest nieomylne nauczanie biskupa Rzymu.

Konsekwencją papieskiej nieomylności jest to, że nauczanie ex cathedra jest samo z siebie, a nie na mocy zgody Kościoła. Taka konsekwencja papieskiej nieomylności oznacza pogrzebanie gallikanizmu głoszącego nadrzędność soboru nad papieżem. Osobnym problemem pozostaje jednak relacja nauczania ex cathedra, które jest samo z siebie, a nie na mocy zgody Kościoła, do Haec sancta. Dekret ten mówi o wyższości soboru nad papieżem. Według Schatza ,jest on ważnym, podstawowym rozstrzygnięciem w przypadku zawsze możliwego, ekstremalnego zawodu spowodowanego przez urząd papieski" ${ }^{34}$. Historia Soboru w Konstancji pokazuje, że urząd papieski może zawieść, ale również sobór może zawieść, jak o tym świadczy Sobór w Efezie z 449 roku, który został przez papieża Leona Wielkiego nazwany latrocinium (stąd nazwa „synod zbójecki”,

${ }^{29}$ J. Wojtkun, Pojęcie „obyczaje” (mores) jako przedmiot nieomylności Urzędu Nauczycielskiego Kościoła, w: Postannictwo biskupa Rzymu, red. J. Jezierski, Olsztyn 2002, s. 175.

${ }^{30}$ Tamże.

${ }^{31}$ L. Ott, Fundamentals of catholic dogma, dz. cyt., s. 287.

${ }^{32}$ H.U. von Balthasar, Antyrzymski resentyment, Poznań 2004, s. 228.

${ }^{33}$ Tamże, s. 366.

${ }^{34}$ K. Schatz, Prymat papieski od początków do wspótczesności, dz. cyt., s. 172. 
w rzeczywistości bardziej odpowiednia byłaby nazwa „synod gangsterski”). „Synod zbójecki" niejako sub contrario podkreśla ważność zdania św. Ambrożego ubi Petrus, ibi ecclesia. Z kolei Sobór w Konstancji podkreśla ważność przeciwnego zdania ubi ecclesia, ibi Petrus. Obydwie wypowiedzi są szczególnie ważne w sytuacjach ekstremalnych, kiedy to zawodzi papież lub sobór, a zatem, czy wypowiedź z Haec sancta o wyższości soboru nad papieżem, jak i wypowiedź Pastor aeternus o nauczaniu ex cathedra stawiającym papieża ponad soborem, nie powinny być traktowane jako rozstrzygnięcia w sytuacjach ekstremalnych?

Wypowiedź Pastor aeternus o nauczaniu ex cathedra, które jest samo z siebie, a nie na mocy zgody Kościoła, rodzi problem wzajemnych relacji pomiędzy papieżem a Kościołem. Problem ten poruszył książę biskup z Brixen Vinzenz Gasser (1809-1879) w przemówieniu na soborze 11 lipca 1870 roku. Zdaniem Gassera, nie można odłączyć papieża od Kościoła, tak jak nie można oddzielić fundamentów od budowli, na których się wspiera. Papież jest nieomylny tylko wtedy, kiedy sprawuje urząd nauczyciela wszystkich chrześcijan. Będąc nauczycielem wszystkich chrześcijan, papież reprezentuje cały Kościół, określając to, w co wszyscy mają wierzyć lub co wszyscy mają odrzucić. Bycie nauczycielem całego Kościoła nie wyklucza, lecz zakłada współdziałanie z Kościołem. Ponieważ papieska nieomylność nie jest wynikiem objawienia czy natchnienia, lecz boskiej asystencji, dlatego papież ma obowiązek podjąć kroki niezbędne do poznania prawdy ${ }^{35}$. Pogląd Gassera współgra z opinią niemieckiego teologa Johanna Adama Möhlera. Relację papieża do soboru pojmuje on jako jeden żywy organizm, w którym każdy człon zdany jest na pozostałe, a pytanie, kto n a d kim stoi, jest niestosowne. Trzeba więc odrzucić zarówno gallikanizm z jego koncyliaryzmem, jak i papalizm stawiający papieża nad soborem. Po linii Gassera i Möhlera idzie Oświadczenie episkopatu niemieckiego na temat stosunku prymatu do urzędu biskupiego (1875):

Pogląd wreszcie, że papież stał się ,mocą swojej nieomylności władcą całkowicie absolutnym", opiera się na zupełnie błędnym zrozumieniu dogmatu o nieomylności papieskiej. Jak to Sobór Watykański w jasnych i wyraźnych słowach zaznaczył i jak wynika z samej istoty rzeczy, nieomylność ta jest jedynie przymiotem najwyższego papieskiego Urzędu Nauczycielskiego. Ten zaś posiada taki sam przedmiot, jak nieomylny Urząd Nauczycielski Kościoła w ogóle i jest związany nauką Pisma św. i Tradycji, jak również dotychczasowymi doktrynalnymi rozstrzygnięciami Urzędu Nauczycielskiego Kościoła ${ }^{36}$.

Papież Pius IX zaaprobował Oświadczenie episkopatu niemieckiego Listem apostolskim Mirabilis illa constantia (4 marca 1875) ${ }^{37}$.

${ }^{35}$ K. Schatz, Vaticanum I 1869-1870, dz. cyt., s. 141.

${ }^{36} \mathrm{H}$. Denzinger, Enchiridion symbolorum definitionum et declarationum de rebus fidei et morum, San Francisco 2012, s. 618-620.

${ }^{37}$ Zob. tamże, s. 620-621. 
Według Dei Filius wiara opiera się na autorytecie objawiającego Boga, który nie może się mylić ani wprowadzać $\mathrm{w}$ błąd $^{38}$. Z kolei Pastor aeternus opiera wiarę na najwyższym apostolskim autorytecie papieża ${ }^{39}$. Obydwa te autorytety nie mogą być sobie przeciwstawiane ani też ze sobą zrównywane. Autorytet papieża jest podporządkowany autorytetowi Boga i dlatego papież nie może ogłaszać jakiejś nowej nauki, ale ma strzec i wiernie wyjaśniać objawienie, za którym stoi autorytet Boga. Wynika to z samej konstytucji Pastor aeternus, „Duch Święty został bowiem obiecany następcom św. Piotra nie dlatego, aby z pomocą Jego objawienia ogłaszali nową naukę, ale by z Jego pomocą święcie strzegli i wiernie wyjaśniali Objawienie przekazane przez apostołów, czyli depozyt wiary" ${ }^{40}$.

\section{Kierunki współczesnej relektury dogmatu o nieomylnym nauczaniu biskupa Rzymu}

Po uroczystym ogłoszeniu dogmatu 18 lipca 1870 roku nad Rzymem zerwała się burza, która była komentowana na różne sposoby. Dla jednych była ona znakiem Bożego gniewu z powodu ubóstwienia człowieka poprzez przyznanie mu Bożego przymiotu, jakim jest nieomylność. Dla drugich burza wkomponowała się w uroczysty pogrzeb gallikanizmu. Dla trzecich była ona odgłosem bram piekielnych uderzających w Piotra - skałę, na której zbudowany jest Kościół. Jeszcze inni mówili: „Jesteśmy na Synaju. Tak jak nadaniu Dekalogu towarzyszyły błyskawice i grzmoty, podobnie teraz towarzyszą one ogłoszeniu dogmatu o nieomylności, bo to właśnie teraz świat został pozbawiony faraona (entfharaont). Mamy teraz Mojżesza, a nawet kogoś większego od Mojżesza" ${ }^{41}$. Z perspektywy czasu wszystkie te opinie można uznać za przesadzone. Owszem, można Soborowi Watykańskiemu I przypisać pogrzebanie gallikanizmu, ale nie można mu przypisać zwycięstwa ultramontanizmu, bo przecież papież nie został uznany za jakiegoś wice-Boga.

Z perspektywy czasu w nieomylnym nauczaniu biskupa Rzymu można widzieć dar dla Kościoła, jak to sugeruje tytuł książki The Gift of infallibility zawierającej soborowe wystapienie Gassera opatrzone komentarzem Jamesa O’Connora. Ten dar papieskiej nieomylności służy jedności Kościoła. Pastor aeternus mówi o tym, aby „cały Kościół był zachowany w jedności” ${ }^{42}$. Jezus

\footnotetext{
${ }^{38}$ Sobór Watykański I, Konstytucja dogmatyczna o wierze katolickiej, dz. cyt., s. 897.

${ }^{39}$ Sobór Watykański I, Pierwsza Konstytucja dogmatyczna o Kościele Chrystusowym, dz. cyt., s. 927.

40 Tamże, s. 925.

${ }^{41}$ K. Schatz, Vaticanum I 1869-1870, dz. cyt., s. 167.

${ }^{42}$ Sobór Watykański I, Pierwsza Konstytucja dogmatyczna o Kościele Chrystusowym, dz. cyt., s. 927.
} 
pośrednio wskazał na jedność królestwa Szatana: „Jeśli więc i szatan z sobą jest skłócony, jakże się ostoi jego królestwo?” (Łk 11,14-26). Jedność Kościoła musi być mocniejsza od owej jedności królestwa Szatana, bo ma być ona obrazem jedności Trójcy Świętej. Dogmat o nieomylnym nauczaniu biskupa Rzymu jest wyrazem troski Soboru o jedność Kościoła. Tylko Kościół katolicki przywiązuje wagę do centrum unitatis, które widzi w biskupie Rzymu. W związku z tym Balthasar uważa, że każdy Kościół niekatolicki jest protestancki. Jest kimś, kto protestuje - mniej czy bardziej - ale zawsze. „Tym, co łączy wszystkich, jest wspólna nienawiść do zespalającej w jedność zasady"43. Odrzucenie centrum unitatis prowadzi do budowania tożsamości wyznaniowej na negacji, przede wszystkim prymatu biskupa Rzymu. W konsekwencji będzie to oznaczało odrzucanie wszystkiego, co naucza biskup Rzymu, a z drugiej strony funkcję odrzucanego biskupa Rzymu zajmie cesarz, car, prezydent czy nawet gensek. Odrzucony ostatecznie przez Sobór Watykański I gallikanizm był lokomotywą ciągnąca Kościół w objęcia świeckiego władcy.

Według Pastor aeternus potrzeby epoki dyktują potrzebę skuteczności urzędu biskupa Rzymu ${ }^{44}$. Ta skuteczność nauczania biskupa Rzymu jeszcze bardziej jest potrzebna w dobie współczesnego relatywizmu. Według Benedykta XVI relatywizm usiłuje stworzyć wrażenie, że wszystko jest względne, że również prawdy wiary zależą od sytuacji historycznej i od ludzkiej oceny ${ }^{45}$. Relatywizm można więc uznać za największą herezję. O ile bowiem dawne herezje brały część za całość, o tyle relatywizm swoim założeniem o nieistnieniu obiektywnej prawdy uderza za jednym zamachem w cały gmach Credo. W sytuacji podejrzeń, a nawet wrogości wobec prawdy Kościół potrzebuje papieskiej nieomylności, której znamionami są szybkość, skuteczność i pewność potwierdzania objawionej Prawdy. Dzięki tym cechom papieskiej nieomylności błąd ma niewielkie szanse, aby rozrosnąć się jak rakowa narośl. Nie zawsze okoliczności mogą pozwolić na szybkie zwołanie soboru. Nie można też wykluczyć przypadku, który opisuje Władimir Sołowjow (1853-1900), w Krótkiej opowieści o Antychryście. Antychryst będzie pacyfista, ekologiem i ekumenistą. Jako ekumenista zwoła sobór, który za cenę ustępstw doktrynalnych, ale i hojnych dotacji Antychrysta-ekumenisty, będzie miał szansę zjednoczyć nie tylko chrześcijan, ale i wyznawców wszystkich religii. Ogół chrześcijan pójdzie za Antychrystem-ekumenista, godząc się na zamianę Kościoła wojującego w Kościół powielający mody tego świata i Kościół politycznie poprawny. Z zamiarami Antychrysta-ekumenisty nie zgodzi się chrześcijanin o symbolicznym imieniu Piotr. Można w nim widzieć

\footnotetext{
${ }^{43}$ H.U. von Balthasar, Antyrzymski resentyment, dz. cyt., s. 92.

${ }^{44}$ Sobór Watykański I, Pierwsza Konstytucja dogmatyczna o Kościele Chrystusowym, dz. cyt., s. 925 .

${ }^{45}$ Benedykt XVI, Homilia (Warszawa), w: Trwajcie mocni w wierze. Benedykt XVI w Polsce, Kraków 2006, s. 47.
} 
biskupów Rzymu, którzy w ekstremalnych sytuacjach, nawet gdyby zawiódł sobór, szybko, skutecznie i pewnie bronią objawionej Prawdy.

Sobór Watykański II nie tylko potwierdził dogmat o nieomylnym nauczaniu biskupa Rzymu, ale włączył go w większą całość. To włączenie dogmatu o nieomylnym nauczaniu biskupa Rzymu w większą całość ukazał papież Jan Paweł II w Liście do Konferencji Episkopatu Niemiec z 15 maja 1980 roku, napisanym w związku ze sprawą profesora Hansa Künga. Według Jana Pawła II Sobór Watykański II przejął od Soboru Watykańskiego I doktrynę o nieomylnym nauczaniu biskupa Rzymu, ,potwierdził ją i przedstawił w kontekście bardziej kompletnym". Tym bardziej kompletnym kontekstem jest nauczanie Konstytucji dogmatycznej o Kościele Lumen gentium o nieomylności kolegium biskupów, gdy wraz z papieżem sprawuje ono najwyższy urząd nauczycielski (25), oraz o nadprzyrodzonym zmyśle wiary całego ludu, dzięki któremu nie może on zbłądzić w wierze (12). Również dokument Międzynarodowej Komisji Teologicznej ,Sensus fidei” $w$ życiu Kościoła przedstawia dogmat o nieomylnym nauczaniu biskupa Rzymu w bardziej kompletnym kontekście. Dogmat ten nie tylko nie ignoruje sensus fidei fidelium, ale je zakłada. W pierwotnym projekcie konstytucji Supremi Pastor, z której uchwalono tylko rozdział zawierający dogmat o nieomylnym nauczaniu biskupa Rzymu, znajdował się rozdział o nieomylności Kościoła. W swojej relacji przedstawiającej nieomylne nauczanie biskupa Rzymu Gasser wyjaśnił, że specjalna asystencja Ducha Świętego dana papieżowi nie oddziela go od Kościoła i nie wyklucza konsultacji i współpracy. Tę konsultację i współpracę ukazał Gasser na przykładzie dogmatu o niepokalanym poczęciu. Papież przed ogłoszeniem tego dogmatu zapytał biskupów, czy przekonanie o niepokalanym poczęciu Matki Pana podzielają powierzeni im wierni (40). Takie przedstawienie nieomylnego nauczania biskupa Rzymu w kontekście bardziej kompletnym pozwala na uniknięcie zarówno papalizmu, jak i episkopalizmu oraz laikalizmu. Papalizm byłby postawieniem papieża ponad Kościołem; episkopalizm - biskupów ponad papieżem, a laikalizm - opinii publicznej ponad nauczaniem papieża i kolegium biskupów. Koniecznym i niełatwym zadaniem teologii pozostaje pogłębienie wzajemnych relacji pomiędzy nieomylnym nauczaniem biskupa Rzymu, nieomylnym nauczaniem kolegium biskupów i nadprzyrodzonym zmysłem wiary całego ludu, dzięki któremu nie może on zbłądzić w wierze. Te niejako trzy podmioty nieomylności Kościoła nie powinny ze sobą konkurować, ale wzajemnie się uzupełniać. Żaden z nich nie może tworzyć niczego nowego w stosunku do objawienia, lecz mają się uzupełniać, gdy chodzi o wyjaśnianie i obronę Bożego objawienia.

W kręgach przeciwników dogmatu o nieomylnym nauczaniu biskupa Rzymu mówiono, że Sobór Watykański I rozpoczął się od „komedii zaproszeń”, a zakończył się „tragedią nieomylności”. Z perspektywy czasu okazuje się, że „komedia zaproszeń” ustąpiła miejsca dialogowi ekumenicznemu. Przykładowo, 
luteranie i katolicy w USA podjęli rozmowy o prymacie (1974) i nieomylności papieskiej (1979). Osiagnięcia dialogów ekumenicznych o prymacie papieskim ukazuje monografia Juliana Nastałka Prymat papieski $w$ dialogu ekumenicznym $w$ polskiej literaturze teologicznej. Ukazując dotychczasowe osiagnięcia dialogu ekumenicznego o prymacie, monografia nie przemilcza tego, co w dalszym ciągu dzieli. Opierając się jednak na tym, co łączy, można mieć nadzieję, że w przyszłości posługa biskupa Rzymu będzie centrum unitatis wierzących w Chrystu$\mathrm{sa}^{46}$. Z kolei „tragedia nieomylności” stała się darem pewności wyznawanej i głoszonej wiary. Można to dostrzec w kontekście współczesnego świata, w którym akceptuje się tylko autorytet funkcjonalny. Na podstawie takiego autorytetu można formułować jedynie hipotezy podlegające ciąłej weryfikacji, a nie ostateczne twierdzenia ${ }^{47}$. Dzięki nieomylnemu nauczaniu biskupa Rzymu wierzący otrzymuje pewność wiary, a nie hipotezy czy pobożne życzenia. „Komedia zaproszeń" i „tragedia nieomylności” okazuje się współcześnie coraz bardziej darem jedności Kościoła i darem pewności wiary.

\section{The Controversy over Papal Infallibility - from Haec sancta to Pastor aeternus}

\section{Summary}

The decree Haec Sancta approved by the Council of Constance at its $5^{\text {th }}$ Session $\left(6^{\text {th }}\right.$ April 1415) helped the Council fathers to put an end to the scandalous schism which since 1378 had divided the Latin Church between rival lines of claimants to the papal office. The Council of Constance declared for the superiority of the Council over the Pope. In Gallicanism the theory of the superiority of a General Council lived on for hundreds of years. The great body of the bishops of the nineteenth century had little sympathy with Gallican principles, which disappeared entirely after the definition of Papal Infallibility at the First Vatican Council in 1870. There are several requirements for a dogmatic, papal infallible pronouncement: (1) The pronouncement must be made by the lawful successor to Peter. (2) The subject matter must be in the area of faith and morals. (3) The pope must be speaking ex cathedra, that is from the very seat and office of Peter. In this way he must be specifically intending to proclaim a doctrine, binding the entire Church to its assent. If one or more of these elements is missing, there is no infallible pronouncement.

\section{Keywords}

Council of Constance, Conciliarism, Gallicanism, First Vatican Council, Papal Infallibility

\section{Słowa kluczowe}

Sobór w Konstancji, koncyliaryzm, gallikanizm, I Sobór Watykański, papieska nieomylność

${ }^{46}$ J. Nastałek, Prymat papieski $w$ dialogu ekumenicznym w polskiej literaturze teologicznej, Świdnica 2008, s. 133.

${ }^{47}$ T. Płonka, Stopniowalność orzeczeń Magisterium Kościoła w nauczaniu Stolicy Apostolskiej podczas pontyfikatu Jana Pawła II, Warszawa 2011, s. 107. 


\section{Bibliografia}

Balthasar H.U. von, Antyrzymski resentyment, Poznań 2004.

Beinert W., Unfehlbarkeit, w: Lexikon für Theologie und Kirche X, Freiburg-Basel-Wien 2006.

Cztery artykuły gallikańskie francuskiego zgromadzenia kleru z 19 marca 1862 roku, w: K. Schatz, Prymat papieski od poczqutków do wspótczesności, Kraków 2004.

Denzinger H., Enchiridion symbolorum definitionum et declarationum de rebus fidei et morum, San Francisco 2012.

Küng H., Nieomylny?, Kraków 1995.

Nastałek J., Prymat papieski w dialogu ekumenicznym w polskiej literaturze teologicznej, Świdnica 2008, s. 133.

Ott L., Fundamentals of catholic dogma, Charlotte 1974.

Płonka T., Stopniowalność orzeczeń Magisterium Kościoła w nauczaniu Stolicy Apostolskiej podczas pontyfikatu Jana Pawła II, Warszawa 2011.

Reinkens J., Über päpstliche Unfehlbarkeit: einige Reflexionen, München 1870.

Robertus Bellarminus, De controversiis christiane fidei adversus hujus temporis haereticos I, lib. II: De Romano Pontifice, cap. 30, w: tenże, Opera omnia I, Napoli 1836, s. $418-420$.

Schatz K., Prymat papieski od poczatków do wspótczesności, Kraków 2004.

Schatz K., Vaticanum I 1869-1870 III, Paderborn-München-Wien-Zürich 1994.

Seweryniak H., Rozwój historyczny pojęcia i roli magisterium, w: Charyzmat osoby $i$ autorytet urzędu, red. G. Strzelczyk, Katowice 2007.

Sobór w Konstancji, Haec sancta, w: Dokumenty Soborów Powszechnych III, Kraków 2003.

Sobór Watykański I, Konstytucja dogmatyczna o wierze katolickiej, w: Dokumenty Soborów Powszechnych IV, Kraków 2004, 913-927.

Sobór Watykański I, Pierwsza Konstytucja dogmatyczna o Kościele Chrystusowym, w: Dokumenty Soborów Powszechnych, IV Kraków 2004.

Trwajcie mocni w wierze. Benedykt XVI w Polsce, Kraków 2006.

Wojtkun J., Pojęcie „obyczaje” (mores) jako przedmiot nieomylności Urzędu Nauczycielskiego Kościoła, w: Postannictwo biskupa Rzymu, red. J. Jezierski, Olsztyn 2002, s. $167-180$. 